\title{
Na památku prof. PhDr. Zdeňka Měřínského, CSc.
}

\section{Zum Andenken an Prof. PhDr. Zdeněk Měřínský, CSc.}

\author{
Jiří Macháček
}

Dne 9. září 2016 ukončil svoji životní pout prof. PhDr. Zdeněk Měřínský, CSc. - dlouholetý vedoucí a profesor Ústavu archeologie a muzeologie Masarykovy univerzity. V profesoru Měřínském ztratila akademická obec svého nepřehlédnutelného člena a mimořádnou osobnost, která vždy vyčnívala z šedivého průměru. Vynikal nejen vysoce nadprůměrnou vědeckou a publikační aktivitou, ale i velkými organizačními schopnostmi, díky nimž zažila jeho katedra v posledním desetiletí nebývalý rozkvět. Nebyl však činný pouze na půdě Masarykovy univerzity. Působil i v řadě odborných grémií na jiných univerzitách či akademických institucích. Patřil k čelním představitelům nejen české archeologie, ale i celé naší vědy. Jeho největší úsilí vždy směřovalo především k poznávání kultury středověku, kterému zasvětil převážnou část své vědeckého života.

Akademická dráha prof. Měřínského nebyla přímá. I když byl po studiích na brněnské univerzitě předurčen $\mathrm{k}$ působení na své alma mater, a dokonce zde v letech 1972 až 1974 pracoval jako asistent Katedry prehistorie FF UJEP v Brně, nedovolily mu nepříznivé politické poměry počátku 70. let ve slibně započaté kariéře pokračovat. Na Masarykovu univerzitu se mohl vrátit až v roce 1992, a to nejdříve jako odborný asistent Historického ústavu. Záhy však přestoupil na Ústav archeologie a muzeologie, kde se v roce 1996 habilitoval v oboru slovanská archeologie a v roce 2000
Am 9. September 2016 endete die Lebensreise von Prof. PhDr. Zdeněk Měřínský, CSc. - dem langjährigen Leiter und Professor der Abteilung für Archäologie und Museologie an der MasarykUniversität. In der Person von Prof. Měřínský verlor die akademische Gemeinde ihr unübersehbares Mitglied und eine außergewöhnliche Persönlichkeit, die immer über den grauen Durchschnitt hinausragte. Charakteristisch war nicht nur seine deutlich überdurchschnittliche Aktivität im Gebiet der Wissenschaft und Publikationen, sondern auch seine großen Organisierungsfähigkeiten, dank denen seine Abteilung in den letzten zehn Jahren einen beispiellosen Aufschwung erlebte. Tätig war er jedoch nicht nur an der Masaryk-Universität. Er wirkte auch in zahlreichen Fachgremien an anderen Universitäten oder in akademischen Institutionen. Er zählte zu den Spitzenrepräsentanten nicht nur der tschechischen Archäologie, sondern unserer ganzen Wissenschaft. Seine größte Bemühung richtete sich immer vor allem auf das Studium der mittelalterlichen Kultur, dem er den Großteil seines wissenschaftlichen Lebens geweiht hat.

Die akademische Bahn von Prof. Měřínský war nicht gerade. Obwohl er nach seinem Studienabschluss an der Brünner Universität zur Wirkung in seiner Alma Mater vorbestimmt war und hier sogar in den Jahren 1972 bis 1974 als Assistent der Abteilung für Vorgeschichte an der Philosophischen Fakultät gearbeitet hatte, konnte er 


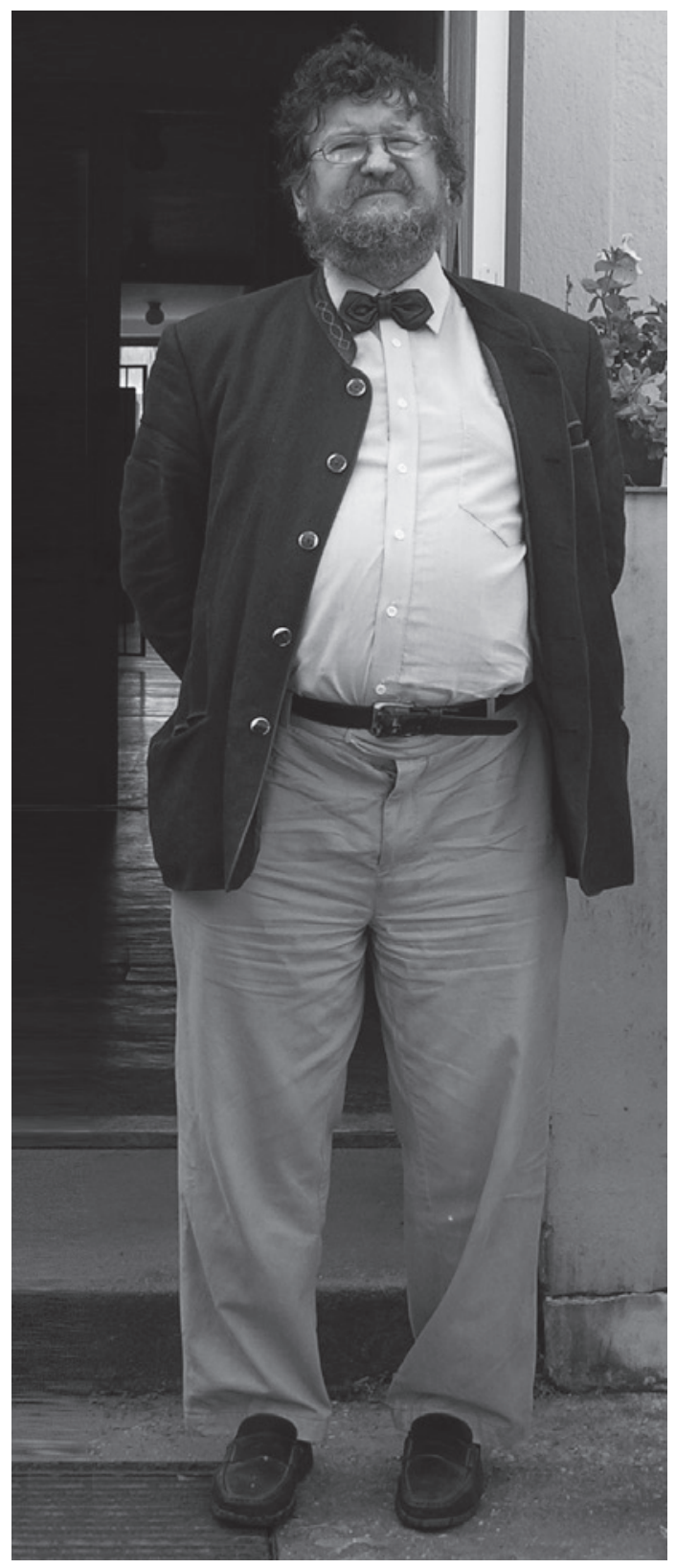

se zde stal i profesorem. V roce 1999 převzal od prof. Vladimíra Podborského vedení ústavu, a to právě v době, kdy mohl být po dlouhých letech ekonomického útlumu 90. let konečně nastartován nový rozvoj vědeckých a pedagogických aktivit ústavu. $\mathrm{V}$ době jeho skonu tvořila pracoviště třicítka akademických, odborných, technických či wegen der ungünstigen politischen Verhältnisse am Anfang der 1970er Jahre seine vielversprechend angefangene Karriere nicht fortsetzen. An die Masaryk-Universität durfte er erst im Jahre 1992 zurückkehren, und zwar zuerst als Fachassistent der Abteilung für Geschichte. Schon bald überwechselte er aber zur Abteilung für Archäologie und Museologie, wo er im Jahre 1996 im Gebiet der slawischen Archäologie habilitiert und im Jahre 2000 auch Professor wurde. Im Jahre 1999 übernahm er von Prof. Vladimír Podborský die Leitung der Abteilung. Es geschah in einer Zeit, wo nach der langen ökonomischen Stagnation der 1990er Jahre endlich eine neue Entwicklungsetappe der wissenschaftlichen sowie pädagogischen Aktivitäten der Abteilung gestartet werden konnte. Zur Zeit seines Ablebens bestand die Abteilung aus dreißig akademischen, fachlichen, technischen oder administrativen Arbeitern. Außer Dutzenden von Bakkalaurei und Magistern studierten hier auch 67 Doktoranden. Zur Erhöhung des Ausbildungsniveaus von neuen wissenschaftlichen Arbeitern hat sicherlich auch die Mährischschlesische Schule für archäologische Doktorstudien beigetragen (in den Jahren 2005-2008 und 2009-2012 zweimal durch die Grantagentur der Tschechischen Republik GA ČR finanziert - Förderungen für die Doktorandenforschung), die von Prof. Měřínský gegründet wurde. Bemerkenswerte Erfolge erreichte die Abteilung für Archäologie und Museologie an der Philosophischen Fakultät der Masaryk-Universität auch im Gebiet der Wissenschaft. Prof. Měřínský selbst erwarb für seine Forschungstätigkeit im Jahre 2012 den Preis der Südmährischen Region und im Jahre 2014 auch die Auszeichnung für langzeitige ausgezeichnete Forschungsergebnisse, die vom Rektor der Masaryk-Universität erteilt wird.

Außer der Organisierungstätigkeit formierte Prof. Měřínský unsere sowie mitteleuropäische Archäologie und Mediävistik auch als aktiver Forscher und unermüdlicher Organisator. Dies bezeugt auch seine außerordentliche Publikationstätigkeit, zu der wir nur schwer irgendwelche Parallelen suchen. Während seiner professionellen Karriere veröffentlichte er 5 Monographien selbständig und 20 weitere als Mitverfasser, und au- 
administrativních pracovníků. Kromě desítek bakalářů a magistrů se zde vzdělávalo i 67 doktorandů. Ke zvyšování úrovně výuky nových vědeckých pracovníků jistě přispěla i Moravskoslezská škola archeologických doktorandských studií (financováno po dvakráte v letech 2005-2008 a 2009-2012 GA ČR - doktorské granty), kterou prof. Měřínský založil. Pozoruhodných úspěchů dosáhl pod jeho vedením Ústav archeologie a muzeologie FF MU také na poli vědeckém. On sám získal za svoji badatelskou činnost v roce 2012 Cenu Jihomoravského kraje a v roce 2014 i Cenu za dlouhodobé vynikající výsledky ve výzkumu, udělovanou rektorem Masarykovy univerzity.

Kromě činnosti organizační formoval prof. Měřínský naši i středoevropskou archeologii a medievistiku také jako aktivní badatel a neúnavný organizátor. Svědčí o tom jeho nebývalá publikační aktivita, k níž jen těžko hledáme paralely. Za svoji dosavadní kariéru publikoval samostatně 5 monografií a 20 dalších jako spoluautor a dále téměř 700 (!) vědeckých studií, článků a dalších textů (výběr do roku 2008 viz Biografie Zdeňka Měřínského ve sborníku $\mathrm{k}$ jeho 60 . narozeninám: Zaměřeno na střredověk. Nakladatelství Lidových novin 2010). Jeho badatelská aktivita nepolevila ani v posledních letech života. Důkazem jsou tři objemné monografie - spíše naučně laděné České země od prríchodu Slovanů I. (2002, 564 stran) a II. (2006, 968 stran) z řady Dějiny českých zemí (nakladatelství Libri), a především vědecká syntéza raného středověku Morava na úsvitu dějin (Brno, 2013, 655 stran). Posledně jmenovanou monografii zkompletoval monumentální řadu Vlastivědy moravské, čímž se zařadil po bok takových osobností naší vědy, jakými byl Jan Janák, Josef Válka, Vladimír Podborský, Jaromír Demek aj. Zapomenout nelze ani na jeho rozsáhlou ediční činnost. Byl vedoucím redaktorem našeho předního medievistického časopisu Archaeologia historica a organizátorem stejnojmenných konferencí. Spolu s Janem Klápště založil řadu Dissertationes Archaeologicae Brunenses/Pragensesque, kde jsou publikovány doktorské práce $\mathrm{z}$ obou našich předních univerzit.

Vědecký i osobní život prof. Měřínského byl úzce spojen s jeho milovanou lokalitou - hradem
Berdem beinahe 700 (!) wissenschaftliche Studien, Artikel und andere Texte (eine Auswahl bis zum Jahre 2008 siehe Biografie von Zdeněk Měřínský im Sammelband $\mathrm{zu}$ seinem 60. Geburtstag: Zaměřeno na středověk. Nakladatelství Lidových novin 2010). Seine Forschungsaktivität ließ auch in den letzten Jahren seines Lebens nicht nach. Den Beweis dafür liefern drei umfangreiche Monographien - die eher didaktisch orientierte Arbeit České země od příchodu Slovanů (Böhmische Länder seit der Ankunft der Slawen) I. (2002, 564 Seiten) und II. (2006, 968 Seiten) aus der Editionsreihe Dějiny českých zemí (Geschichte der Böhmischen Länder; Verlag Libri) und vor allem die wissenschaftliche Synthese des Frühmittelalters Morava na úsvitu dějin (Mähren an der Schwelle der Geschichte) (Brno, 2013, 655 Seiten). Mit der letztgenannten Monographie komplettierte er die monumentale Editionsreihe Vlastivěda moravská (Mährische Landeskunde), womit er sich neben solche Persönlichkeiten unserer Wissenschaft wie Jan Janák, Josef Válka, Vladimír Podborský, Jaromír Demek u. a. eingereiht hat. Erwähnen muss man auch seine umfangreiche Editionsarbeit. Er war Chefredakteur von unserer wichtigsten mediävistischen Zeitschrift Archaeologia historica und Organisator von gleichnamigen Konferenzen. Zusammen mit Jan Klápště gründete er die Editionsreihe Dissertationes Archaeologicae Brunenses/ Pragensesque, wo die Doktorarbeiten aus den beiden wichtigsten Universitäten in der Tschechischen Republik veröffentlicht werden.

Das wissenschaftliche sowie persönliche Leben von Prof. Měřínský war eng mit seiner beliebten Fundstelle verbunden - mit der Burg Rokštejn in der Nähe von Jihlava. Die Ausgrabungen, die er hier im Jahre 1981 eröffnete, zählen heutzutage $\mathrm{zu}$ den komplexesten und systematischsten Unternehmen dieser Art in Mitteleuropa. Die Freilegung der Burg leitete er mit großer fachlicher Gelehrsamkeit. Vor allem dank Prof. Měřínský entstand im unweiten Dorf Panská Lhota die dritte wissenschaftliche Forschungsbasis der Abteilung für Archäologie und Museologie, wo sich die nötige technische Ausrüstung konzentriert und wo auch die Funde aus den langjährigen Ausgrabungen deponiert sind. 
Rokštejnem na Jihlavsku. Výzkum, který zde v roce 1981 zahájil, dnes patří k nejkomplexnějším a nejsystematičtějším akcím svého druhu ve střední Evropě. Odkryv hradu řídil s velkou odbornou erudicí. Především zásluhou prof. Měřínského vznikla v nedaleké Panské Lhotě třetí vědecko-výzkumná stanice Ústavu archeologie a muzeologie, kde je soustředěno nezbytné technické zázemí a kde jsou deponovány i nálezy z mnohaletého výzkumu.

Svět prof. Měřínského však nevymezovala pouze archeologie. Byl člověkem vpravdě renesančním. Mnoho práce odvedl i na poli historie, kterou po několik let vyučoval jako odborný asistent na Historickém ústavu Filozofické fakulty, zůstával v kontaktu s etnografí́, kterou spolu s archeologií vystudoval, byl také velkým znalcem umění i aktivním malířem, a dokonce organizovaným filatelistou. Zdeněk Měřínský nenaplňoval představu mnoho lidí o vysokoškolském profesorovi jako nepraktickém člověku, odtrženém od normálního života. Opak byl pravdou. Kvưli sanaci „svého“ hradu jednal s projektanty i úřady, kontroloval osobně práci řemeslníků, sháněl stavební materiál i potřebné finance. Sám vykonal práci, na kterou jinde potřebují celé týmy lidí.

Prof. Měřínský měl silně vyvinuté sociální cítění. Potvrdit to mohou mnozí kolegové a žáci, které jejich profesor podpořil ve složitých životních okamžicích. Na druhou stranu byl i mužem pevných zásad. Své názory neměnil a pokud učinil rozhodnutí, dovedl ho důsledně prosadit s razancí sobě vlastní. Přesto na pracovišti, které řídil, vládla velmi liberální atmosféra, která př́la svobodnému bádání. Jeho výsledkem byl rozkvět archeologie na Masarykově univerzitě, která se v době jeho působení rozpínala od neolitu po vrcholný středověk, od jižní Moravy po Sýrii, od vlastních terénních odkryvů po aplikaci nejmodernějších informačních technologii a metod.

Zdenëk Měrinský bude celému Ústavu archeologie a muzeologie chybèt nejen jako vynikajici odbornik, oblibený pedagog a nezpochybnitelná autorita, ale predevším jako vzácný člověk.
Die Welt von Prof. Měřínský war jedoch nicht nur durch Archäologie determiniert. Er war tatsächlich ein Renaissancemensch. Viel Arbeit hat er auch im Gebiet der Geschichte geleistet, die er einige Jahre lang als Fachassistent in der Abteilung für Geschichte der Philosophischen Fakultät unterrichtet hatte. Er blieb im Kontakt mit Ethnographie, die er zusammen mit Archäologie studierte, er war ebenfalls ein großer Kunstkenner und aktiver Maler und sogar organisierter Philatelist. Zdeněk Měřínský erfüllte nicht die weitverbreitete Vorstellung, nach welcher der Universitätsprofessor ein unpraktischer und vom Leben abgetrennter Mensch sein soll. Das Gegenteil war wahr. Wegen der Sanierung „seiner“ Burg verhandelte er mit Projektanten und Behörden, kontrollierte persönlich die Arbeit der Handwerker, besorgte das Baumaterial sowie die nötigen Finanzmittel. Er selbst hat eine solche Menge Arbeit gemacht, für die woanders ganze Teams benötigt werden.

Prof. Měřínský hatte ein stark entwickeltes Sozialgefühl. Bestätigen können es viele seiner Kollegen und Schüler, die ihr Professor in komplizierten Lebensmomenten unterstützte. Auf der anderen Seite war er auch ein Mann von festen Prinzipien. Seine Ansichten hat er nicht geändert und wenn er eine Entscheidung getroffen hat, war er imstande, sie konsequent und mit typischer Rasanz durchzusetzen. In der Institution, die er geleitet hat, herrschte trotzdem eine sehr liberale Atmosphäre, die der freien Forschung positiv geneigt war. Das Ergebnis davon war ein Aufschwung der Archäologie an der Masaryk-Universität, die sich zur Zeit seiner Wirkung vom Neolithikum bis zum Hochmittelalter, von Südmähren nach Syrien und von der Feldforschung selbst bis zur Anwendung der modernsten Informationstechnologien und Methoden ausgedehnt hat.

Zdeněk Měřnský wird der ganzen Abteilung für Archäologie und Museologie fehlen - nicht nur als ein ausgezeichneter Experte, beliebter Pädagoge und eine unbezweifelbare Autorität, sondern vor allem als ein einzigartiger Mensch. 